Abstract-With the southern New England lobster fishery in distress, lobster fishermen have focused more effort toward harvesting channeled whelk (Busycotypus canaliculatus). However, minimal research has been conducted on the life history and growth rates of channeled whelk. Melongenid whelks generally grow slowly and mature late in life, a characteristic that can make them vulnerable to overfishing as fishing pressure increases. We sampled channeled whelk from Buzzards Bay, Massachusetts, in August 2010 and in July 2011, studied their gonad development by histology, and aged them by examining opercula. Males had a slower growth rate and a lower maximum size than females. Male whelk reached $50 \%$ maturity $\left(\mathrm{SM}_{50}\right)$ at $115.5 \mathrm{~mm}$ shell length (SL) and at the age of 6.9 years. Female whelk reached $\mathrm{SM}_{50}$ at $155.3 \mathrm{~mm} \mathrm{SL}$ and at the age of 8.6 years. With a minimum size limit of $69.9 \mathrm{~mm}$ (2.75 in) in shell width, males entered the fishery at 7.5 years, a few months after $\mathrm{SM}_{50}$, but females entered the fishery at 6.3 years, approximately 2 years before $\mathrm{SM}_{50}$. Increased fishing pressure combined with slow growth rates and the inability to reproduce before being harvested can easily constrain the long-term viability of the channeled whelk fishery in Massachusetts.

Manuscript submitted 25 September 2012. Manuscript accepted 28 May 2013. doi 10.7755/FB.111.3.5

Fish. Bull. 111:265-278 (2013).

The views and opinions expressed or implied in this article are those of the author (or authors) and do not necesarily reflect the position of the National Marine Fisheries Service, NOAA.

\title{
Age, size, and sexual maturity of channeled whelk (Busycotypus canaliculatus) in Buzzards Bay, Massachusetts
}

\author{
Bhae-Jin Peemoeller (contact author) ${ }^{1}$ \\ Bradley G. Stevens ${ }^{2}$ \\ Email address for contact author: bhaejin@gmail.com \\ 1 Department of Natural Sciences \\ University of Maryland Eastern Shore \\ Carver Hall \\ Princess Anne, Maryland 21853 \\ Present address for contact author: 5013 Smith Farm Road \\ Virginia Beach, Virginia 23455 \\ ${ }^{2}$ Living Marine Resources Cooperative Science Center \\ Department of Natural Sciences \\ University of Maryland Eastern Shore \\ Carver Hall \\ Princess Anne, Maryland 21853
}

The channeled whelk (Busycotypus canaliculatus: Melongenidae) supports a small but growing fishery in Massachusetts. Most fishing is conducted by lobstermen during the off-season (spring and fall) or when the lobster fishery is slow; therefore, fishing of this species typically is done on a part-time basis. However, channeled whelk landings in Massachusetts increased substantially after 2000, as the southern New England lobster stock declined, and reached 1400 metric tons in 2011 with a value of $\$ 6.2$ million (Glenn and Wilcox $\left.^{1}\right)$. In addition, exvessel prices have nearly doubled from 2007 to 2011 , increasing the incentive to expand effort in this fishery (Glenn and Wilcox ${ }^{1}$ ). Fishing pressure may affect the average size of whelks because many fishermen may focus on catching larger whelks (>160 mm shell length [SL]). Davis and Sisson (1988) reported declines in population density and mean shell width

\footnotetext{
${ }^{1}$ Glenn, R., and S. Wilcox. 2012. Profile of the channeled whelk pot fishery, $9 \mathrm{p}$. Report to the Massachusetts Marine Advisory Commission. Massachusetts Division of Marine Fisheries, Invertebrate Fisheries Program, 1213 Purchase St., New Bedford, MA 02740.
}

(maximum distance across shell) for channeled whelk in Nantucket Sound between 1978 and 1981. Bruce (2006) reported a decrease in mean SL between 1994 and 2004 for a related species, knobbed whelk (Busycon carica), subject to a dredge fishery in Delaware Bay.

Most whelk research has been conducted on knobbed whelk, and minimal research has been done on channeled whelk (Avise et al., 2004; Bruce, 2006; Castagna and Kraeuter, 1994; Eversole et al., 2008; Kraeuter et al., 1989; Power et al. ${ }^{2}$; Walker et al., 2005; Walker et al., 2007). Because of limited information on growth rates and size at maturity, managers do not know if the current minimum size limit of $69.9 \mathrm{~mm}(2.75$ in) in shell width (SW) is appropriate to ensure the reproduction and longevity of channeled whelk in Mas-

2 Power, A. J., C. J. Sellers, and R. L. Walker. 2009. Growth and sexual maturity of the knobbed whelk, Busycon carica (Gmelin, 1791), from a commercially harvested population in coastal Georgia, 24 p. Occasional Papers of the University of Georgia Marine Extension Service, vol. 4. Marine Extension Service, Univ. Georgia, Shellfish Research Laboratory, Savannah, GA. 
sachusetts and to sustain the fishery for this species. The minimum size limit was established by the State of Massachusetts on the basis of the size of market acceptability (Glenn and Wilcox ${ }^{1}$ ). With increased fishing pressure and limited biological information, channeled whelk can easily become overfished, especially if they are not able to reproduce before they enter the fishery.

The channeled whelk ranges from Cape Cod, Massachusetts, to Cape Canaveral, Florida (Edwards and Harasewych, 1988). Growth rate and size at maturity for channeled whelk are virtually unknown, but whelks of the family Melongenidae typically are slow growing, late maturing animals. In the seaside lagoons of Virginia, knobbed whelk reach a mean size of $176.1 \mathrm{~mm}$ SL in 9-11 years (Kraeuter et al., 1989). In South Carolina, knobbed whelk <90 mm SL grow faster than larger whelk (up to 7 times faster), although some knobbed whelk have minimal or negative growth (Eversole et al., 2008). It has been suggested that channeled whelk have low fecundity because they lay egg strings only once a year (Edwards and Harasewych, 1988). Betzer and Pilson (1974) reported an annual change in gonad index (fresh weight of the gonad/fresh weight of whole soft tissues) of channeled whelk in Narragansett Bay, Rhode Island, with spawning most likely occurring in late summer and fall. No studies have been published that provide the spawning season of channeled whelk or the environmental factors, such as temperature and salinity, at which they spawn. In a study of this species in aquaria, channeled whelk began hatching from an egg string on 18-30 April 2010 at water temperatures of $15-18^{\circ} \mathrm{C}$; the egg string was collected on 1 March 2010 near Cedar Island, Virginia (Harding, 2011).

Channeled whelk may have a similar reproductive cycle to that of knobbed whelk. On intertidal flats in Virginia, knobbed whelk copulated in June and July and laid egg strings from mid-August to November; hatching occurred from mid-March to early May (Castagna and Kraeuter, 1994). Knobbed whelk egg cases found in Cedar Island, Virginia, in 1977 yielded an average of 3770 whelk per string (Castagna and Kraeuter, 1994). However, information on the fecundity of channeled whelk is needed. The mode of reproduction for whelks also needs investigation because Castagna and Kraeuter (1994) suggested that knobbed whelk may be protandrous hermaphrodites. Knobbed whelk raised in a laboratory were all males at 9 years, but, after 13 years, some males changed sex, and at the age of 14 years, produced viable offspring (Castagna and Kraeuter, 1994). This outcome is contrary to the findings of Avise et al. (2004), who determined that knobbed whelk are genetically dioecious and sex is determined at birth.

Aging opercula gives insight on the growth and longevity of channeled whelk. Ilano et al. (2004) reported that striae form annually on the operculum of Buccinum isaotakii and can be used to estimate age. HeudeBertherlin et al. (2011) counted the number of striae on the operculum of waved whelk (Buccinum undatum) to determine age. Kraeuter et al. (1989) aged knobbed whelk by embedding opercula in plastic resin and then sectioning them. For validation of aging, they used laboratory-reared knobbed whelk and embedded the opercula of 3 knobbed whelk of $6+$ years and 3 knobbed whelk of $7+$ years. Kraeuter et al. (1989) reported the average ages of these knobbed whelk at 6.0 and 7.2 years, respectively. Another aging technique involves bleaching knobbed whelk opercula and counting annuli (Bruce et al. ${ }^{3}$ ). In the opercula of older knobbed whelk, Power et al. ${ }^{2}$ found a "bubbling effect," from growth ring overlap, due to decreased growth rates.

There are no published reports on the histological staging of channeled or knobbed whelk gonads. We began this study to provide useful biological information, such as size and age at sexual maturity, for managers of the channeled whelk fishery in Massachusetts. Data on the size at sexual maturity will provide managers with information needed to set minimum size limits that allow females to spawn at least once and, therefore, to help prevent overfishing (Gordon, 1994). We sampled channeled whelk in Buzzards Bay, Massachusetts, and expected that they would be protandrous hermaphrodites as reported for laboratory-reared knobbed whelk by Castagna and Kraeuter (1994). We hypothesized that SL would increase with age and that slower growth would occur at older ages. We provide the first information on the relationship between size, age, and stages of gonad development for channeled whelk and on the size and age at $50 \%$ maturity $\left(\mathrm{SM}_{50}\right)$ of male and female channeled whelk.

\section{Materials and methods}

\section{Sampling}

Sampling was conducted off Massachusetts in Buzzards Bay, a large, semi-enclosed estuary in the northeastern United States (Fig. 1). Buzzards Bay is uniformly shallow, with depths mostly at $10-15 \mathrm{~m}$, and is open to the sea at multiple locations. As a result, the water column in this bay is extremely well mixed, and differences between surface and bottom temperatures rarely exceed $1^{\circ} \mathrm{C}$, and salinities are almost uniformly 30 ppt (Turner et al., 2009). Commercial wooden or wire mesh conch traps, baited with the Atlantic horseshoe crab (Limulus polyphemus), were used to collect channeled whelk from Buzzards Bay in August 2010 and in July 2011. Traps varied in size but were generally $50 \times 50 \times 30 \mathrm{~cm}$, and they were set at depths of $10-15 \mathrm{~m}$ at 10-12 different sites in each year to maximize catches. Traps were allowed to soak for 1 week, and they were retrieved weekly over a 4 -week period each year. Channeled whelk were identified according to Pollock

\footnotetext{
${ }^{3}$ Bruce, D. G., R. Wong, and M. Greco. 2006. Delaware Bay whelk (conch) fishery assessment 2005, 36 p. Delaware Division of Fish and Wildlife, 89 Kings Highway, Dover, DE 19901.
} 
(1998). Whelk from different sites were mixed; sites sampled in 2010 were mostly in eastern Buzzards Bay, and those sites sampled in 2011 were mostly in western Buzzards Bay. Because we mixed whelk from a large number of sites, we did not measure water temperature at individual sites; instead, seawater temperatures were examined from the NOAA Data Buoy Station BZBM3, at the Northeast Fisheries Science Center dock in Woods Hole, Massachusetts (NOAA station 8447930, http://www.ndbc.noaa.gov/station_history.php?station=bzbm3).

We measured whole wet weight (Wt) of shell and tissue to the nearest $0.1 \mathrm{~g}$, SL to the nearest $0.1 \mathrm{~mm}$, and lip width (LW, maximum distance across the upper edge of the largest whorl) to the nearest $0.1 \mathrm{~mm}$. Length of the male copulatory organ (penis length), measured to the nearest $0.1 \mathrm{~mm}$, was recorded for 93 males only in 2011. We also measured the SW for the first 166 whelk. Although SW is very similar to the measurement used by fishermen and managers for the minimum size limit, channeled whelk have an asymmetrical shell structure, and there is no standard procedure for measuring SW. We used LW instead of SW as our primary width measurement because it was more easily replicated and more precise than SW; the mean coefficient of variation for whelk in 5-mm intervals of LW was 2.14 times greater for SW than for LW, with a range from 1.21 to 4.13 for $\mathrm{SW}$.

For this study, 292 channeled whelk (155 females and 137 males) were sampled through the random selection of at least 20 whelk of various sizes in each 10-mm-SL interval. In 2010, we filled most of our SL intervals except for the intervals for very small $(<100 \mathrm{~mm}$ SL) and very large (>190 mm SL) whelk. In 2011, we focused on the collection of whelk from these unfilled SL intervals to extend the sampling range for this study. After whelk were weighed and measured, we cracked their shells with a hammer to determine sex. Males were defined as those whelk with a penis, and females were defined as those whelk with a nidamental gland. Scissors were used to separate the gonad from the digestive gland (gonads were not weighed). We removed the entire gonad from smaller whelk ( $<120 \mathrm{~mm}$ SL), and larger whelk had an approximately $2-\mathrm{cm}$ section removed from the terminal end of the gonad (closest to the tip of the shell spire) to the start of the gonad (closest to the operculum). Gonads were stored in $10 \%$ formalin for 1 week before they were transferred to $80 \%$ ethanol (EtOH) (Stoner et al., 2012).

\section{Age analysis}

Opercula from our dissected channeled whelk were removed with a scalpel, labeled, and stored in $10 \%$ for-

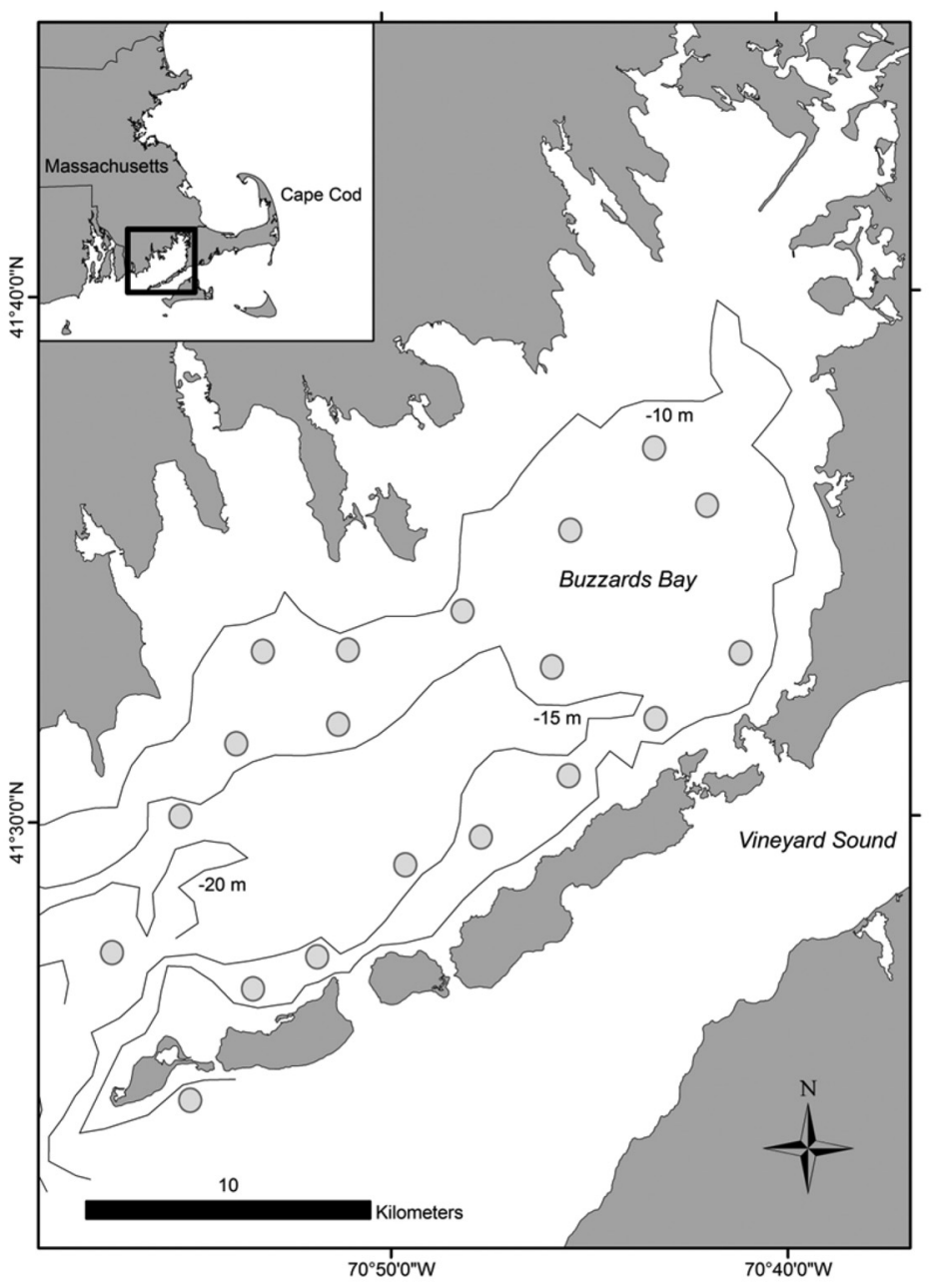

Figure 1

Map of approximate capture sites (gray circles) of channeled whelk (Busycotypus canaliculatus) collected in August 2010 and July 2011 in Buzzards Bay, Massachusetts. Specimens came from numerous sites within Buzzards Bay; however, capture site was not recorded for each whelk.

malin for 1 week, and then transferred to $70 \%$ EtOH. Whelk opercula were taken out of EtOH, bleached for 30 min with $5 \%$ sodium hypochlorite, and then blotted dry with paper towels. Annuli were defined as growth striae that form on the interior margin and extend across the operculum to the exterior margin (Fig. 2; Bruce et $a .^{3}$ ). The first annulus of each operculum generally had a 6-mm linear distance that ranged from the interior to the exterior margin. To count annuli, opercula were placed under a light source and photographed with an Olympus Stylus 4004 4-megapixel digital camera (Olympus Optical Co., Ltd., Center Valley, PA). Opercula did not dry and curl during this pro-

\footnotetext{
${ }^{4}$ Mention of trade names or commercial companies is for identification purposes only and does not imply endorsement by the National Marine Fisheries Service, NOAA.
} 


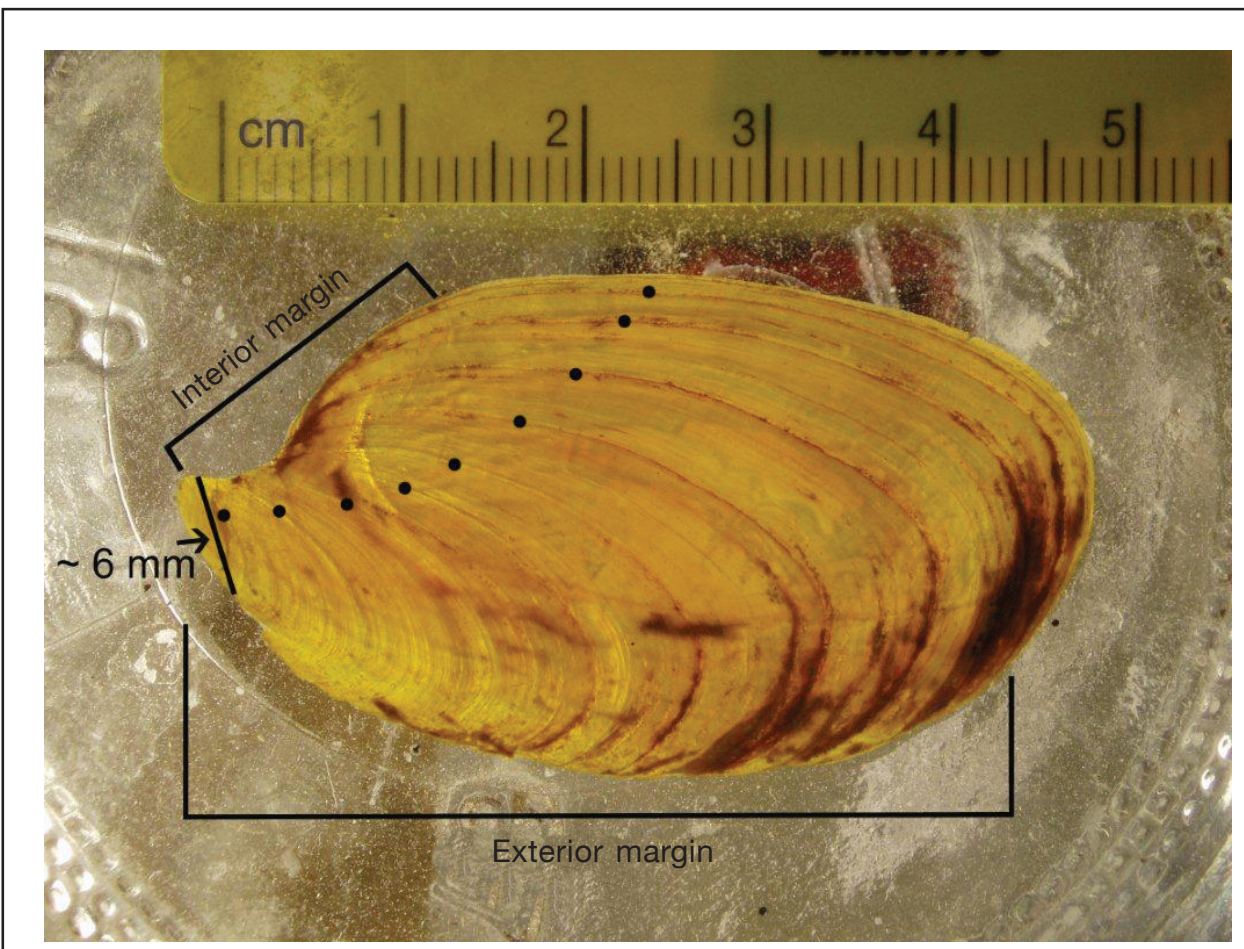

Figure 2

Image of the operculum of a 9-year-old male (142.9 $\mathrm{mm}$ shell length) channeled whelk (Busycotypus canaliculatus). Readers counted annuli to determine the age of whelk collected for our study in August 2010 and July 2011 in Buzzards Bay, Massachusetts. Dots are placed on each annulus for reference. The interior margin is at the top of this opercula, and the exterior margin is at the bottom. For the first annulus of each operculum examined in our study, there generally was a 6 - $\mathrm{mm}$ linear distance from the interior to the exterior margin.

If all 3 readers recorded different ages, the mean value (rounded to the nearest year) was used if variance was $\leq 1$ (equivalent to a confidence bound of \pm 2 years); whelk with greater variance were determined to be unacceptable. Only 227 whelk (115 females and 112 males) of 292 total dissected whelk (155 females and 137 males) were used for operculum analysis (Table 1 ).

\section{Histology and gonad staging}

A histological examination of gonads from 112 males and 115 females was undertaken to determine gonad development stage. Not all dissected whelks (155 females and 137 males) were used for analysis because some opercula were not determined acceptable for operculum analysis and, therefore, could not be used for the comparison of age with gonad development. Two tissue samples

cess, and shrinkage was not a concern because counting of annuli did not depend on accurate measurement of widths of annuli.

Each operculum was read by 3 readers to estimate age (Kraeuter et al., 1989). Each reader recorded their confidence for each operculum, a technique similar to the one used by Herbst and Marsden (2011) to age otoliths for Lake Whitefish (Coregonus clupeaformis). Confidence levels for aging channeled whelk opercula were defined as 1) not confident-the initial year's growth was at least partially missing and annuli were difficult to distinguish because of opaque or dark zones on the operculum; 2) somewhat confident-the initial year's growth was partially missing but the shape was reasonably approximated; annuli were partially obscured by washed out or dark zones but were reasonably approximated; 3) confident-operculum showed initial year's growth and annuli were easily readable; or 4) very confident-operculum exhibited strongly prominent annuli that were easy to read.

We analyzed operculum only from whelk with an average confidence rating $\geq 2$. If 2 of the 3 readers recorded the same age for an operculum, that age was used. were processed from each whelk gonad with a TissueTek VIP-E150 (Sakura Fineteck USA, Inc., Torrence, CA) automated tissue processor that contained a dehydration series of $70 \% \mathrm{EtOH}, 95 \% \mathrm{EtOH}$, and various concentrations of $100 \% \mathrm{EtOH}$ and clearing agent and melted paraffin. Tissue samples were taken from a onethird portion and a two-thirds portion (approximately $5 \mathrm{~mm}$ apart) of the gonad sample to address synchrony within the gonad. The processed tissues were embedded in paraffin and sectioned to $10 \mu \mathrm{m}$ (male) or 14 $\mu \mathrm{m}$ (females). Each tissue sample produced 4 replicates, which were mounted on slides and dried on a slide warmer. The best 2 slides from each tissue sample (4 slides per gonad) were stained with a haematoxylin and eosin stain; coverslips were then mounted with a resin mounting medium.

Four slides from each whelk gonad were examined to determine sex and gonad stage. The dominant stage was defined as the stage that represented at least $50 \%$ of the section (Ilano et al., 2003). If both tissue samples from a whelk's gonad had different dominant stages, then the most advanced stage was recorded. The classifications for each stage followed descriptions of Buc- 
cinum isaotakii (e.g., Ilano et al., 2003) and Rapana venosa (e.g., Mann et al., 2006). Male gonads exhibited 4 stages: immature (I), early developing (ED), late developing (LD), and mature (M). Male maturity was classified on the basis of the presence of spermatozoa in the tubule and not on the basis of density. For classification in a fifth stage, the recovering $(R)$ stage, males would be expected to exhibit elongate tubules with few remaining spermatozoa. No males were considered in the $\mathrm{R}$ stage because all males with elongate tubules had $\geq 50 \%$ of tubules with spermatozoa and were subsequently reported as in the mature stage. Female gonads exhibited 5 stages: I, ED, LD, M, and R. Female maturity was determined on the basis of the amount of vitellogenic oocytes (VOs) present in the cross section.

\section{Statistical analyses}

Linear regression relationships between SL, LW, and Wt were calculated and compared through the use of covariance analysis to determine if there was a relationship between sex and shell size or shape (Stoner et al., 2012). A significant coefficient $(P<0.05)$ meant that either slope or intercept differed between males and females. As a prerequisite for covariance analysis, an $F$-test was used to ensure that the variance between males and females was not significantly different. Data were $\log _{10}$ transformed for the relationship between SL and Wt because Wt increased nonlinearly to SL. For the comparison of $\log _{10} S L$ and sex to $\log _{10} W t$, sex was a factor and $\log _{10} S L$ was a covariate.

The von Bertalanffy growth model has been used to describe the growth of gastropods, such as the queen conch (Strombus gigas) (e.g., Berg and Olsen, 1989) and Buccinum isaotakii (e.g., Ilano et al, 2004). Shell length and estimated age for each channeled whelk were used to fit a von Bertalanffy growth model, for each sex separately (Ricker, 1975):

$$
L_{\mathrm{a}}=L_{\mathrm{inf}}\left(1-\mathrm{e}^{-K\left(a-t_{0}\right)}\right),
$$

where $L_{\mathrm{a}}=$ the SL (in millimeters) at age (years);

$L_{\text {inf }}=$ the theoretical maximum SL;

$K=$ the growth coefficient;

$a=$ the age; and

$t_{0}=$ the theoretical age at length 0 .

A von Bertalanffy growth model that compared LW (in millimeters) and estimated age also was conducted, with LW replacing SL where appropriate. The annual growth rate (in SL) for each sex was calculated by subtracting the size at each age from the size at age +1 from the von Bertalanffy growth model. Growth rate and age were square-root (sqrt) transformed and covariance analysis was used to determine if sex affects growth. The sqrt transformation was used because a $\log _{10}$ transformation yielded nonlinear results. The regression of sqrt-transformed $S L$ growth versus age and sex included sex as a factor and sqrt (age) as a covariate and was expressed (in terminology of $R$ statisti- cal software [R Development Core Team, 2011]) in this manner:

$$
\text { sqrt }(S L \text { growth }) \sim \operatorname{sqrt}(\text { age }) * \text { sex, }
$$

where indicates a relationship ("modeled as") and * indicates the combination of the factors sqrt (age) + sex and the interaction of sqrt (age) by sex. All further regression equations used this terminology and were computed with $\mathrm{R}$ statistical software ( $\mathrm{R}$ Development Core Team, 2011).

On the basis of results of reproductive histology, we classified as mature any whelk with gonads in stage $\mathrm{M}$ or $\mathrm{R}$. These data were used to calculate a nonlinear logistic regression by using a general linear model (GLM) with a binomial link function, with SL, LW, or age as the size measurement, and the GLM regression coefficients were used to estimate the size at which channeled whelk of each sex reached $\mathrm{SM}_{50}$ with the following formula:

$$
S M_{50}=-B_{0} \cdot B_{1}^{-1},
$$

where $B_{0}=$ the intercept; and

$$
B_{1}=\text { the slope. }
$$

Because the $\mathrm{SM}_{50}$ equation gives only a single value for each data set (male or female), a bootstrap routine was used to resample each data set with replacement 1000 times, and the results were used to calculate the bias and standard error (SE) of the original mean value of $\mathrm{SM}_{50}$. Bias was calculated through the subtraction of the original (full data set) value of $\mathrm{SM}_{50}$ from the resampled mean value of $\mathrm{SM}_{50} \cdot \mathrm{SM}_{50}$ is a widely accepted predictor of sexual maturity for various shellfishes, including the queen conch (e.g., Stoner et al., 2012), waved whelk (e.g., Heude-Bertherlin et al., 2011), and Zidona dufresnei (e.g., Giménez and Penchaszadeh, 2003). In our study, the fitted values of the GLM, representing the proportion of mature whelk, were plotted against either SL or LW. For comparison, the proportion of mature whelk was calculated from the raw data within $10-\mathrm{mm}$ increments of SL or $5-\mathrm{mm}$ increments of LW and plotted. To compare the LW at which each sex reached $\mathrm{SM}_{50}$ with the current minimum size limit for harvest, we conducted a regression that compared the LW of 166 channeled whelk to their SW, the measurement similar to the one used to specify the legal size limit. All $\mathrm{SM}_{50}$ values are given as mean $\pm 1 \mathrm{SE}$, and all statistics were computed with $\mathrm{R}$ ( $\mathrm{R}$ Development Core Team, 2011).

\section{Results}

\section{Staging gonads}

Seawater temperatures at Woods Hole in the sampling months of August 2010 and July 2011 averaged $22.2^{\circ} \mathrm{C}$ ( $\mathrm{SE} 0.7$ ) and $22.2^{\circ} \mathrm{C}$ (SE 0.6), respectively, and were not significantly different, but mean temperatures in August were $1.2^{\circ} \mathrm{C}$ greater in 2011 than in 2010 . To our 
knowledge, there is no other published information about temperatures during the spawning season of channeled whelk, but our data do not allow inferences to be made about temperature effects on spawning because we sampled only during 1 month in each of 2 years and did not sample throughout the entire spawning season.

Histological examination showed that male channeled whelk classified as stage I of gonad development had small circular tubules that contained no spermatozoa and few spermatogonia, spermatocytes, and spermatids (Fig. $3 \mathrm{~A}$ ). The cross section contained connective tissue and empty space. Males assigned to stage ED had $<25 \%$ of tubules with spermatozoa (Fig. 3B). There were few spermatogonia, spermatocytes, and spermatids present, and some empty space was still visible in the cross section. Males in stage LD had $25-50 \%$ of tubules with spermatozoa; more spermatogonia, spermatocytes, and spermatids were present and tubules were more elongate than they were in males in earlier stages (Fig. 3C). Males classified as stage $M$ had $\geq 50 \%$ of tubules with spermatozoa; tubules were elongate and contained many spermatogonia, spermatocytes, and spermatids (Fig. 3D).

Female channeled whelk classified in development stage I had gonads with minimal previtellogenic oocytes (PVOs), no nuclei present, and empty space in the cross section; connective tissue was more prevalent than it was in later stages, as seen in males classified as stage I (Fig. 3E). Females in stage ED had more developed PVOs that contained round nuclei and visible nucleoli than did females in the earlier stage (Fig. 3F). Females identified as LD generally had $<50 \%$ of the cross section with VOs (Fig. 3G). The VOs were larger and more elongate than the PVOs, although some PVOs still were present in the gonad. Females classified as $\mathrm{M}$ had $\geq 50 \%$ of the cross section with VOs, which were elongate and full of large yolk granules (Fig. $3 \mathrm{H}$ ). Females in stage $\mathrm{R}$ had some elongate oocytes and some small oocytes that were empty or had minimal PVOs or VOs (Fig. 3I).

\section{Morphological relationships}

The ratio of females to males in our sample of dissected channeled whelk was near unity at the size range of $90-110 \mathrm{~mm}$ SL (Table 1) and ages of 4-6 years (Table 2). The smallest size intervals (70-90 $\mathrm{mm}$ SL) were male dominated, although not many individuals in that range were caught (Table 1). Male whelk had a lower maximum size and age than female

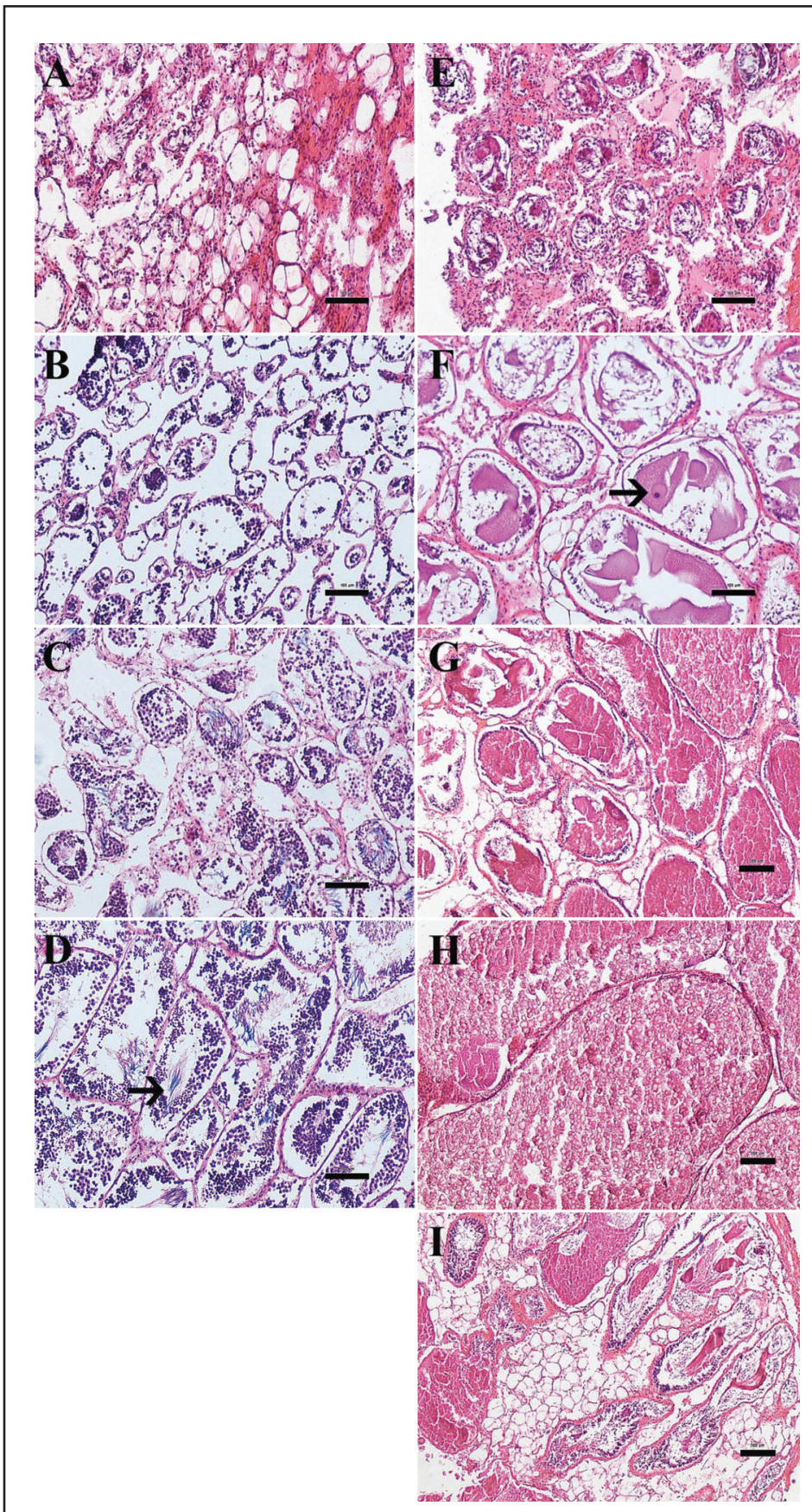

Figure 3

Histological photographs of the stages of gonad development for (A-D) male and (E-I) female channeled whelk (Busycotypus canaliculatus) used in our study to classify whelk collected in Buzzards Bay, Massachusetts, in July 2010 and August 2011. Observed male gonad stages: (A) immature; (B) early developing; (C) late developing; and (D) mature, with arrow pointing to spermatozoa. Observed female gonad stages: (E) immature; (F) early developing, with arrow pointing to a nucleus (also containing a nucleolus) from a previtellogenic oocyte; (G) late developing; (H) mature female with vitellogenic oocytes full of large yolk granules; and (I) recovering. Scale bars are set at $100 \mu \mathrm{m}$ for panels $\mathrm{A}-\mathrm{F}$ and $200 \mu \mathrm{m}$ for panels $\mathrm{G}-\mathrm{I}$. 


\section{Table 1}

Number and proportion of each sex by interval of shell length (SL) for channeled whelk (Busycotypus canaliculatus) collected in August 2010 and July 2011 in Buzzards Bay, Massachusetts. Lower and Upper SL describe the range for each interval and is measured in millimeters. For the age and gonad analyses in our study, we used 112 males and 115 females.

\begin{tabular}{cccccc}
\hline Lower SL & Upper SL & Males & Females & $\begin{array}{c}\text { Proportion } \\
\text { male }\end{array}$ & $\begin{array}{c}\text { Proportion } \\
\text { female }\end{array}$ \\
\hline 70 & 80 & 3 & 0 & 1.00 & 0.00 \\
80 & 90 & 7 & 1 & 0.88 & 0.13 \\
90 & 100 & 9 & 6 & 0.60 & 0.40 \\
100 & 110 & 7 & 8 & 0.47 & 0.53 \\
110 & 120 & 13 & 5 & 0.72 & 0.28 \\
120 & 130 & 16 & 2 & 0.89 & 0.11 \\
130 & 140 & 20 & 1 & 0.95 & 0.05 \\
140 & 150 & 20 & 2 & 0.91 & 0.09 \\
150 & 160 & 16 & 3 & 0.84 & 0.16 \\
160 & 170 & 1 & 11 & 0.08 & 0.92 \\
170 & 180 & 0 & 19 & 0.00 & 1.00 \\
180 & 190 & 0 & 19 & 0.00 & 1.00 \\
190 & 200 & 0 & 16 & 0.00 & 1.00 \\
200 & 210 & 0 & 18 & 0.00 & 1.00 \\
210 & 220 & 0 & 4 & 0.00 & 1.00 \\
& & & & & \\
\hline
\end{tabular}

between sexes and that male and female intercepts were similar (Tables 3 and 4). The LW covariance analysis indicates that males and females have a similar initial size, but male LW may differ from female LW as SL increases.

\section{Growth rate}

The von Bertalanffy growth models for the sexes were significantly different (Table 5; Fig. 4, A and B). The oldest female was 14 years old, and males reached a maximum age of 12 years. Males and females had similar SL until about the age of 4 years, after which the curve for males started to plateau (Fig. $4 \mathrm{C})$. Females reached a larger maximum size and had higher annual growth rates than males (Fig. 4, C and D). The growth rates for males and females decreased as age increased (Fig. 4D). Covariance analysis of sqrt ( $S L$ growth) versus sqrt (age) and sex indicated that the intercepts were not significantly different, and the male slope was significantly less than the female slope (Table 4). The sqrt ( $S L$ growth) covariance analysis indicates

whelk. Males dominated the size range of 110-160 mm SL and ages of 7-9 years, and females dominated the size intervals above $160 \mathrm{~mm}$ SL and ages of 1014 years (Tables 1 and 2). For the 137 dissected male channeled whelk, the maximum SL recorded was 175.0 $\mathrm{mm}$ and the maximum Wt was $490.6 \mathrm{~g}$. Females typically grew larger than males, reaching a maximum SL of $214.2 \mathrm{~mm}$ and a maximum Wt of $930.0 \mathrm{~g}(n=155)$.

Penis length increased with SL in males (Table 3). The single exception was a $199.3-\mathrm{mm}$ male that was removed from the study because histology showed that this whelk's gonad was nonfunctional. Its gonad was empty of any gonadal precursors and contained only connective tissue. The sex of the whelk could not be determined on the basis of the gonad. It was recorded as a male only because a small penis (15 $\mathrm{mm}$ in length) was detected; a mature male at $165 \mathrm{~mm}$ SL normally would have a penis approximately $37 \mathrm{~mm}$ long.

There was an exponential relationship between SL and Wt and a linear relationship between SL and LW. Covariance analysis of $\log _{10} W t$ to $\log _{10} S L$ and sex (Table 4) showed that the male intercept and male slope were not significantly different from the female intercept and female slope. The results of this covariance analysis of $\log _{10} W t$ indicate that $\log _{10} W t$ regression equations for males and females are similar (Table 3). Because sex was not a significant factor, a combined regression equation that included both sexes was calculated and indicated that $\log _{10} W t$ was significantly related to $\log _{10} S L$ (Tables 3 and 4). Covariance analysis of $L W$ versus $S L$ and sex showed that slopes differed that males and females had a similar initial size, but male and female growth rates differed over time.

\section{Size at $50 \%$ maturity}

Females classified in stage I of gonad development did not exceed $130 \mathrm{~mm}$ SL (Fig. 5A) and 8 years of age (Fig. 5C). Females identified as ED did not exceed 160

\section{Table 2}

Number and proportion of each sex by age in years for channeled whelk (Busycotypus canaliculatus) collected in August 2010 and July 2011 in Buzzards Bay, Massachusetts. For the age and gonad analyses in our study, we used 112 males and 115 females.

\begin{tabular}{rcccc}
\hline Age & Male & Female & $\begin{array}{c}\text { Proportion } \\
\text { male }\end{array}$ & $\begin{array}{c}\text { Proportion } \\
\text { female }\end{array}$ \\
\hline 4 & 1 & 1 & 0.50 & 0.50 \\
5 & 5 & 5 & 0.50 & 0.50 \\
6 & 12 & 10 & 0.55 & 0.45 \\
7 & 27 & 5 & 0.84 & 0.16 \\
8 & 26 & 5 & 0.84 & 0.16 \\
9 & 27 & 8 & 0.77 & 0.23 \\
10 & 9 & 21 & 0.30 & 0.70 \\
11 & 3 & 34 & 0.08 & 0.92 \\
12 & 2 & 15 & 0.12 & 0.88 \\
13 & 0 & 5 & 0.00 & 1.00 \\
14 & 0 & 6 & 0.00 & 1.00 \\
& & & & \\
\hline
\end{tabular}


Table 3

Regression equations, sample sizes, coefficients of multiple determination $\left(R^{2}\right)$, standard errors, and $P$-values for penis length, whole wet weight (Wt), lip width (LW), and shell width (SW) as functions of shell length (SL), LW, or SW from our study of channeled whelk (Busycotypus canaliculatus) collected in August 2010 and July 2011 in Buzzards Bay, Massachusetts. Standard error (SE) is $\pm 1 \mathrm{SE}$.

\begin{tabular}{llcccc}
\hline Regression & \multicolumn{1}{c}{ Equation } & $\begin{array}{c}\text { Sample } \\
\text { size }(n)\end{array}$ & $R^{2}$ & $\begin{array}{c}\text { Standard } \\
\text { error }\end{array}$ & $P$-value \\
\hline Penis length & $-249.171+128.982 * \log _{10} S L$ & 92 & 0.801 & 4.048 & $<2.2 \mathrm{e}-16$ \\
Female $\log _{10} \mathrm{Wt}$ & $-4.437+3.139 * \log _{10} S L$ & 115 & 0.978 & 0.049 & $<2.2 \mathrm{e}-16$ \\
Male $\log _{10} \mathrm{Wt}$ & $-4.204+3.027 * \log _{10} S L$ & 112 & 0.956 & 0.053 & $<2.2 \mathrm{e}-16$ \\
Log $_{10} \mathrm{Wt}$ & $-4.385+3.114 * \log _{10} S L$ & 227 & 0.979 & 0.051 & $<2.2 \mathrm{e}-16$ \\
Female LW & $3.699+0.504 * S L$ & 115 & 0.976 & 2.779 & $<2.2 \mathrm{e}-16$ \\
Male LW & $6.453+0.473 * S L$ & 112 & 0.958 & 2.177 & $<2.2 \mathrm{e}-16$ \\
SW & $-9.607+1.233^{*} L W$ & 166 & 0.938 & 2.933 & $<2.2 \mathrm{e}-16$ \\
LW & $11.954+0.761 * S W$ & 166 & 0.938 & 2.304 & $<2.2 \mathrm{e}-16$ \\
& & & & & \\
\hline
\end{tabular}

mm SL (Fig. 5A) and 9 years of age (Fig. 5C). No LD or $\mathrm{R}$ females exceeded $190 \mathrm{~mm}$ SL (Fig. 5A), although there were females assigned as $\mathrm{LD}$ at the age of 12 years and females identified as stage $R$ at the age of 14 years (Fig. 5C). The largest males classified as stage I were $120 \mathrm{~mm}$ SL; males identified as ED did not exceed $130 \mathrm{~mm}$ SL, and LD males did not exceed $140 \mathrm{~mm}$ SL (Fig. 5B). Similar to females in stages I and ED, males in stages I and ED did not exceed the ages of 8 years and 9 years, respectively; however, the ages of LD males also were not older than 9 years (Fig. $5 \mathrm{D})$. Females were assigned to stage $\mathrm{M}$ as small as $159 \mathrm{~mm} \mathrm{SL}$ and at 8 years of age, and males were classified in stage M as small as $104 \mathrm{~mm}$ SL and at 6 years of age (Fig. 5). Both males and females included relatively few LD individuals, indicating that spawning had not yet occurred and development was not yet complete.

\section{Table 4}

Covariance analysis on regressions of channeled whelk (Busycotypus canaliculatus) growth in weight (Wt), lip width (LW), and square-root (Sqrt) shell length (SL) from our study of this species collected in August 2010 and July 2011 in Buzzards Bay, Massachusetts. Sample size for each regression was 112 male and 115 female channeled whelk. The female intercept and slope are as stated. The actual male intercept is calculated by adding the male intercept estimate to the female intercept estimate. The actual male slope is calculated by adding the male slope estimate to the female slope estimate. Standard error (SE) is $\pm 1 \mathrm{SE}$.

\begin{tabular}{|c|c|c|c|c|}
\hline Regression & Coefficient & Estimate & $\begin{array}{l}\text { Standard } \\
\text { error }\end{array}$ & $P$-value \\
\hline \multirow[t]{4}{*}{$\log _{10} W t \sim \log _{10} S L * \operatorname{sex}$} & Female intercept & -4.437 & 0.103 & $<2 \mathrm{e}-16$ \\
\hline & Female slope & 3.139 & 0.046 & $<2 \mathrm{e}-16$ \\
\hline & Male intercept & 0.233 & 0.162 & 0.151 \\
\hline & Male slope & -0.112 & 0.075 & 0.138 \\
\hline \multirow[t]{2}{*}{$\log _{10} W t \sim \log _{10} S L$} & Intercept & -4.385 & 0.066 & $<2 \mathrm{e}-16$ \\
\hline & Slope & 3.114 & 0.030 & $<2 \mathrm{e}-16$ \\
\hline \multirow[t]{4}{*}{$L W \sim \mathrm{SL} * \operatorname{sex}$} & Female intercept & 3.699 & 1.168 & 0.002 \\
\hline & Female slope & 0.504 & 0.007 & $<2 \mathrm{e}-16$ \\
\hline & Male intercept & 2.754 & 1.814 & 0.130 \\
\hline & Male slope & -0.031 & 0.013 & 0.015 \\
\hline \multirow{4}{*}{ Sqrt $(S L$ growth $) \sim \operatorname{sqrt}($ age $) * \operatorname{sex}$} & Female intercept & 7.919 & 0.052 & $<2 \mathrm{e}-16$ \\
\hline & Female slope & -1.496 & 0.018 & $<2 \mathrm{e}-16$ \\
\hline & Male intercept & -0.039 & 0.073 & 0.594 \\
\hline & Male slope & -0.209 & 0.026 & $4.63 \mathrm{e}-08$ \\
\hline
\end{tabular}


The average proportion of mature channeled whelk in each interval (10 $\mathrm{mm}$ SL or $5 \mathrm{~mm} \mathrm{LW}$ ) were plotted along with the fitted logistic maturity curves from the GLM for each sex in Figures $6 \mathrm{~A}$ and $6 \mathrm{~B}$, respectively. Estimated male $\mathrm{SM}_{50}$ was $115.5 \mathrm{~mm} \mathrm{SL}$ (SE 2.2), and $61.3 \mathrm{~mm}$ LW (SE 0.9) (Table 6; Fig. 6, $\mathrm{A}$ and $\mathrm{B})$. Estimated female $\mathrm{SM}_{50}$ was $155.3 \mathrm{~mm}$ SL (SE 3.0) and $80.6 \mathrm{~mm} \mathrm{LW}$ (SE 1.9) (Table 6; Fig. 6, A and B). Estimated male and female age at $\mathrm{SM}_{50}$ was 6.9 years (SE 0.2 ) and 8.6 years (SE 0.3), respectively (Table 6). Conversion of LW to SW through regression yielded an $\mathrm{SM}_{50}$ of $66.0 \mathrm{~mm} \mathrm{SW}$ ( $\mathrm{SE}$ 2.9) and $89.7 \mathrm{~mm} \mathrm{SW}$ (SE 2.9) for males and females, respectively (Table 3 ). The $\mathrm{SW}$ regression was not sex specific. The current minimum size limit $(69.9 \mathrm{~mm} \mathrm{SW})$ was equivalent to a size of $65.1 \mathrm{~mm} \mathrm{LW} \mathrm{(SE} \mathrm{2.3)} \mathrm{(Table} \mathrm{3).} \mathrm{From} \mathrm{the} \mathrm{von} \mathrm{Ber-}$ talanffy growth model, age at minimum size limit was calculated as 7.5 years (7.0-7.9 years) and 6.3 years (6.1-6.6 years) for males and females, respectively (Table 5).

\section{Discussion}

This article describes the first published study on reproductive maturity and growth in channeled whelk, and it provides the first estimates of size at maturity for this species. Males reached $\mathrm{SM}_{50} 2$ years before females did. In addition, on the basis of SL, male $\mathrm{SM}_{50}$ was $40 \mathrm{~mm}$ less than female $\mathrm{SM}_{50}$. Male channeled whelk reached $\mathrm{SM}_{50}$ at 66.0 $\mathrm{mm}$ SW (SE 2.9), which is below the minimum legal size limit in Massachusetts. However, females reached $\mathrm{SM}_{50}$ at $89.7 \mathrm{~mm}$ SW (SE 2.9), $20 \mathrm{~mm}$ greater than the minimum size limit. This result indicates that males have a greater chance of copulation before they are harvested than do females, many of which are captured before they reach sexual maturity. Females enter the fishery at an age of 6.3 years, approximately

\section{Table 5}

Estimates for the parameters of shell length (SL) or lip width (LW) for male and female channeled whelk (Busycotypus canaliculatus) from the von Bertalanffy growth model used in our study of this species in Buzzards Bay, Massachusetts, in August 2010 and July 2011. Each estimate is given as value \pm 1 standard error (SE). $L_{\mathrm{inf}}=$ theoretical maximum $\mathrm{SL}$; $K$ =growth coefficient; $t_{0}=$ theoretical age at length 0 .

\begin{tabular}{lcccc}
\hline Model & $\begin{array}{c}\text { Sample } \\
\text { size }(n)\end{array}$ & $L_{\text {inf }}$ & $K$ & $t_{0}$ \\
\hline Female SL & 115 & $247.15(21.63)$ & $0.15(0.04)$ & $1.78(0.59)$ \\
Female LW & 115 & $126.40(10.10)$ & $0.16(0.04)$ & $1.73(0.59)$ \\
Male SL & 112 & $177.80(20.01)$ & $0.20(0.08)$ & $1.63(0.88)$ \\
Male LW & 112 & $89.11(8.79)$ & $0.22(0.08)$ & $1.40(0.95)$ \\
& & & & \\
\hline
\end{tabular}

2 years before they reach $\mathrm{SM}_{50}$. In contrast, males enter the fishery at an age of 7.5 years, a few months after they reach $\mathrm{SM}_{50}$. Although the annual growth rate was higher for female channeled whelk than for male whelk, females took longer to reach $\mathrm{SM}_{50}$. Male waved
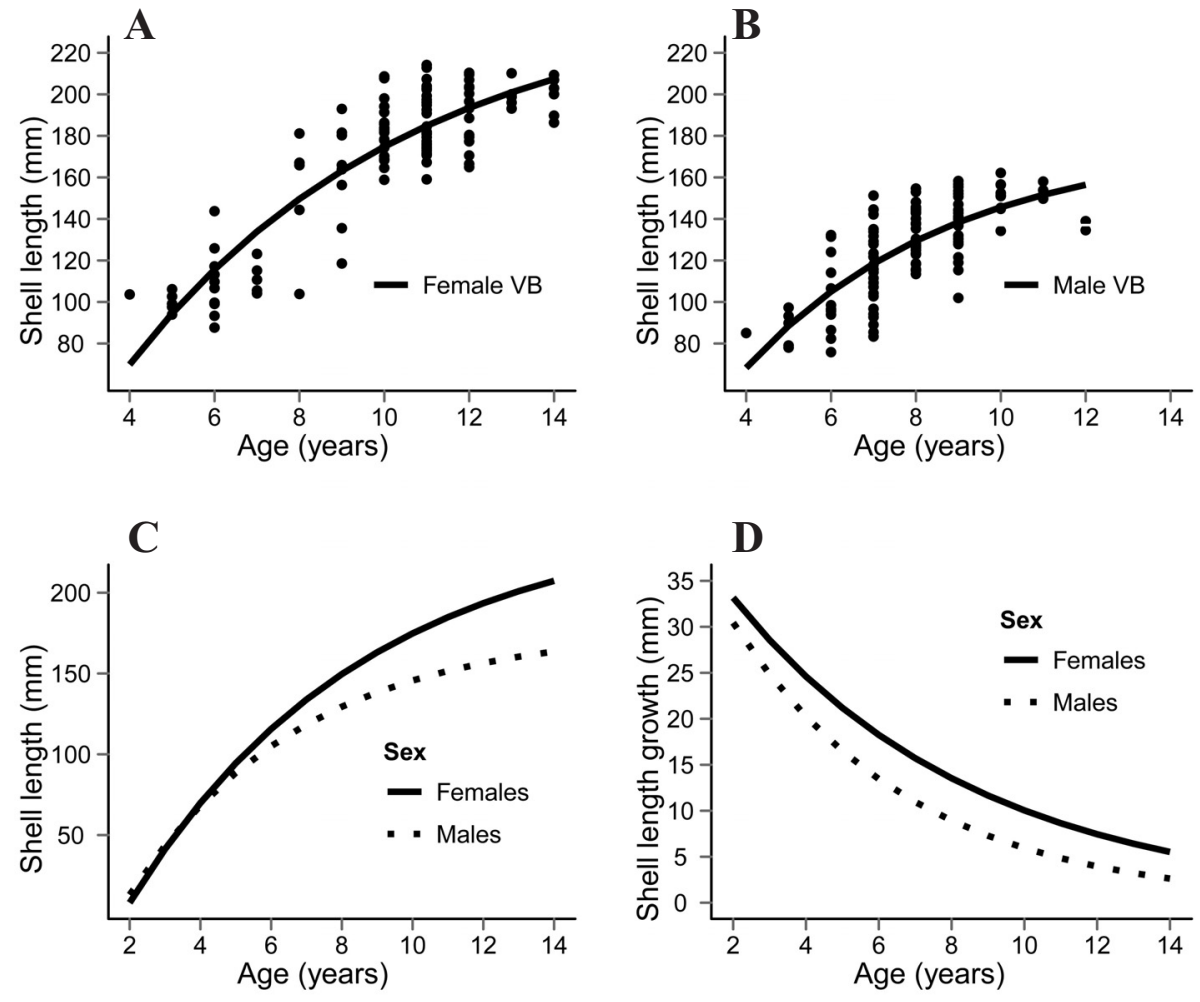

Figure 4

Results from the von Bertalanffy (VB) growth model used in our study of channeled whelk (Busycotypus canaliculatus) collected in Buzzards Bay, Massachusetts, in August 2010 and July 2011: (A) VB growth model of females $(n=115)$; (B) VB growth model of males $(n=112)$; (C) a comparison of male and female VB growth models; and (D) the calculated growth per year for males and females from the VB growth model. 


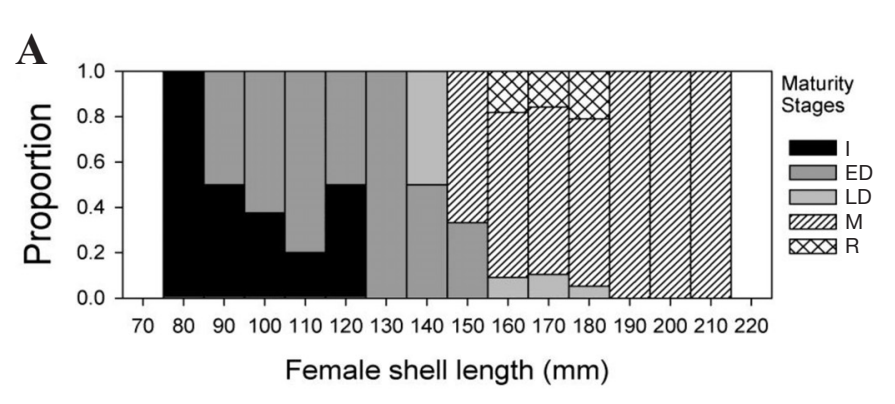

B

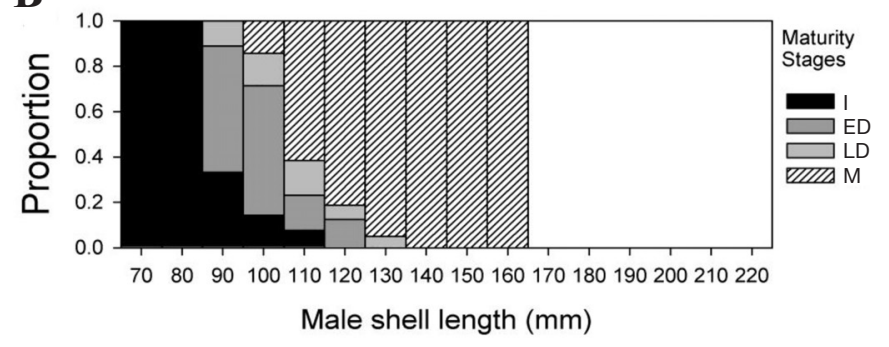

C

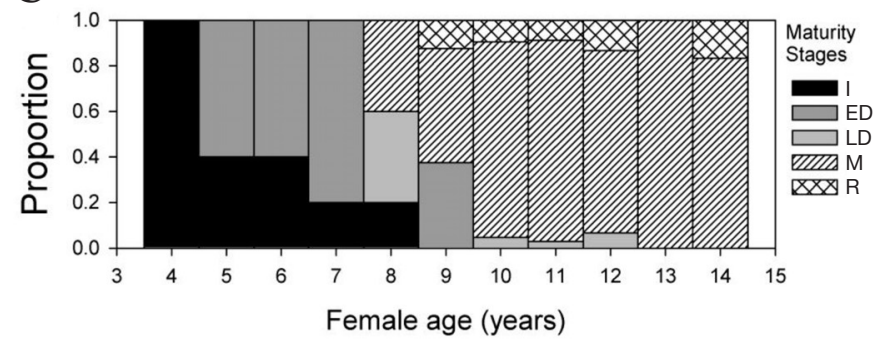

D

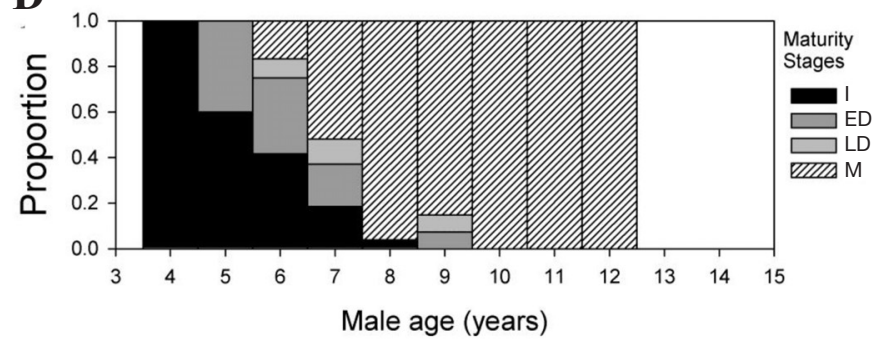

Figure 5

Proportions of channeled whelk (Busycotypus canaliculatus) classified at different stages of gonad development in our study of this species in Buzzards Bay, Massachusetts, in August 2010 and July 2011, shown by varying shell lengths (for [A] females and [B] males) and by varying ages (for [C] females and [D] males). The maturity stages used in our study and presented here are immature (I), early developing (ED), late developing (LD), mature (M), and recovering (R). For gonad analysis, we used 115 females and 112 males.

whelk also reach $50 \%$ maturity before females do, at an age of 3 years versus 4 years (Heude-Bertherlin et al., 2011). Sustainability of the channeled whelk population is of concern for this fishery because effort and incentives are biased toward catch of larger whelk, which are almost entirely female.

The highest growth rate for males and females occurred in the first few years of life. Growth rate progressively decreased as channeled whelk aged (Fig. 4D). There was a wide range of SL at each age for this species (Fig. 4, $\mathrm{A}$ and $\mathrm{B}$ ). This variation also was evident in knobbed whelk in Delaware Bay (Bruce et al. ${ }^{3}$ ) and Buccinum isaotakii (Ilano et al., 2004), both of which were aged by examining opercula.

Harding (2011) reported an average size of $3.8 \mathrm{~mm}$ SL at hatching for channeled whelk cultured from hatch in the laboratory. At 171 days after hatching, the average SL was 48.4 $\mathrm{mm}$; a linear growth model for age-at-length resulted in a growth rate of $0.21 \mathrm{~mm} /$ day (Harding, 2011). In our study of wild channeled whelk, the von Bertalanffy growth model predicted that an average SL of $48.4 \mathrm{~mm}$ would not be achieved until the age of 3 years, indicating a much slower growth rate for whelks in our study than the one found by Harding (2011). Although we did not capture channeled whelk younger than 4 years old, the von Bertalanffy growth model predicted that 3-year-old males and females would be only $41.3 \mathrm{~mm}$ SL and $43.5 \mathrm{~mm} \mathrm{SL}$, respectively (Fig. 4C; Table $5)$. The discrepancy in growth rates between channeled whelk in our study and the whelk in the Harding (2011) study possibly reflects individual variation, although food availability, predator abundance, and habitat may affect shell growth as well.

Channeled whelk held in laboratory tanks may be more protected from shell damage than channeled whelk in their natural environment. Channeled whelk have thin shells and can easily chip their shells (or siphons) while they feed or move around on the ocean floor. In addition, channeled whelk in a laboratory may be exposed to more food than they would be if they were in the ocean. Bourdeau (2010) reported that the frilled dogwinkle (Nucella lamellosa), a marine snail, had thicker shells and reduced shell growth when in the presence of red rock crab (Cancer productus). Food-limited snails did not significantly differ from snails exposed to crab, indicating food consumption, instead of a physiological response from predation, ultimately affected growth (Bourdeau, 2010). These factors that affect SL growth may partially explain the quicker growth rates in Harding (2011) compared with the rates found in our study.

Although knobbed whelk are in a different genus and have thicker shells than channeled whelk (Magalhaes, 1948), both whelks share similar growth pat- 
terns. From the von Bertalanffy growth model, estimates of SL for 10-year-old male and female channeled whelk were 145.7 $\mathrm{mm}$ and $174.8 \mathrm{~mm}$, respectively (Fig. 4C; Table 5). Kraeuter et al. (1989) reported knobbed whelk in the seaside lagoons of Virginia with SL of $176 \mathrm{~mm}$ after 10 years (average for ages $9-11$ ). Bruce et al. ${ }^{3}$ reported 10-year-old knobbed whelk in Delaware Bay with average SL of $112.8 \mathrm{~mm}$ and $127.6 \mathrm{~mm}$ for males and females, respectively. The Delaware Bay population of knobbed whelk appears stunted (possibly because of heavy fishing pressure from the whelk dredge fishery) when compared with the Virginia population. Error in aging opercula also could attribute to shorter SL at age in Delaware Bay. Channeled whelk and knobbed whelk share sexual dimorphism in maximum size. The largest male knobbed whelk in Delaware Bay reached an SL of $161 \mathrm{~mm}$; whereas the largest female reached an SL of $197 \mathrm{~mm}$ (Bruce et al. ${ }^{3}$ ). In Buzzards Bay, Massachusetts, the second-largest male had an SL of $175 \mathrm{~mm}$, but the largest female reached an SL of $214.2 \mathrm{~mm}$. The largest male found in Buzzards Bay was deemed reproductively unviable and subsequently discarded from our analysis.

Females had a slightly larger LW at larger SL when compared with males. This finding could be due to the presence of the nidamental gland, which takes up a large portion of shell volume in mature females. Fe-
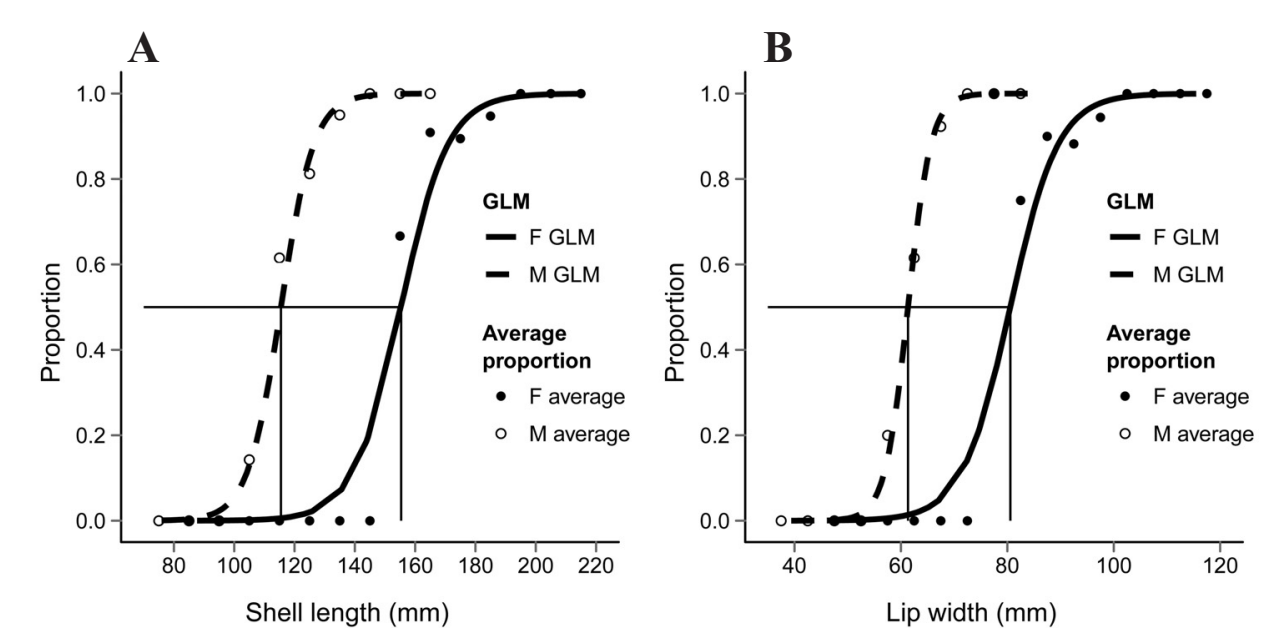

Figure 6

Size at 50\% maturity $\left(\mathrm{SM}_{50}\right)$, on the basis of (A) shell length (SL) or (B) lip width (LW), for male (M) and female (F) channeled whelk (Busycotypus canaliculatus) collected in August 2010 and July 2011 in Buzzards Bay, Massachusetts. Lines indicate predictions from a generalized linear model (GLM); points represent the average proportion within each size interval of $10 \mathrm{~mm}$ SL or $5 \mathrm{~mm} \mathrm{LW}$. Vertical lines indicate $\mathrm{SM}_{50}$. For age and gonad analysis, we used 115 females and 112 males.

\section{Table 6}

Estimates of size at $50 \%$ maturity $\left(\mathrm{SM}_{50}\right)$ by shell length (SL), lip width (LW), and age for male and female channeled whelk (Busycotypus canaliculatus) collected for our study in Buzzards Bay, Massawith replacement 1000 times with a bootstrap routine to calculate the resampled $\mathrm{SM}_{50}$ estimate and the bias and standard error ( $\mathrm{SE}$ ) $\mathrm{SM}_{50}$ estimate from the resampled $\mathrm{SM}_{50}$ estimate. Standard error (SE) is $\pm 1 \mathrm{SE}$ around the original $\mathrm{SM}_{50}$ estimate.

\begin{tabular}{lcclcc}
\hline Sex & $\begin{array}{c}\text { Sample } \\
\text { size }(n)\end{array}$ & Subject & $\begin{array}{c}\text { SM } \\
\text { estimate }\end{array}$ & Bias & SE \\
\hline Female & \multirow{2}{*}{115} & Age & 8.6 years & 0.0014 & 0.3 \\
& & SL & $155.3 \mathrm{~mm}$ & 0.24 & 3.0 \\
& & LW & $80.6 \mathrm{~mm}$ & 0.11 & 1.9 \\
Male & \multirow{2}{*}{112} & Age & 6.9 years & -0.0027 & 0.2 \\
& & SL & $115.5 \mathrm{~mm}$ & 0.12 & 2.2 \\
& & LW & $61.3 \mathrm{~mm}$ & 0.04 & 0.9
\end{tabular}

male waved whelk invest more energy in reproduction than do males of that species: $3.84 \mathrm{kj} \cdot \mathrm{m}^{-2} \cdot \mathrm{yr}^{-1}$ versus $0.26 \mathrm{kj} \cdot \mathrm{m}^{-2} \cdot \mathrm{yr}^{-1}$, respectively (Kideys et al., 1993). The nidamental gland is essential for forming egg cases and may require channeled whelk females to spend more energy on reproduction than do males. Channeled whelk males only need to form a penis and testis, which may explain why males have a lower maximum size.

Males and females had a similar relationship of Wt to SL, although females grew to larger sizes. We expected that the weights of males and females would differ because females form ovaries and a nidamental gland, which would alter the relationship between Wt and SL at larger SL. Castagna and Kraeuter (1994) reported the seasonal gonad index of nidamental gland per meat weight (N/MW) at a range of $9.5-18.3 \%$ for female knobbed whelk. N/MW was lowest in the spring and in October; there has been no field observations reported for knobbed whelk spawning in the spring, although observed egg laying peaked in October (Castagna and Kraeuter, 1994). Despite the in- 
crease in LW and the subsequent increase in volume of female shells, the lack of any observed difference in the relationship of Wt and SL could have occurred because the nidamental gland has a lower density than the density of muscle tissue.

During dissections of channeled whelk in our study, there were no signs of hermaphroditism; all whelk had either a penis or a nidamental gland. No whelk were found to contain both male and female gonads in histological sections. Male penis length increased with SL, a finding that also indicates channeled whelk may not be protandric hermaphrodites. In knobbed whelk, the penis of males that changed sex to females shrank to a round protuberance (Castagna and Kraeuter, 1994). The results of Castagna and Kraeuter (1994) indicate knobbed whelk can be protandric hermaphrodites, although sex is determined at birth and there is a 1:1 sex ratio at hatching (Avise et al., 2004).

We found an equal sex ratio for male and female channeled whelk at early ages, but later, males dominated at ages of 7-9 years and females dominated at ages of 10-14 years (Table 2). Males did not live as long as females (Table 2), and there was a greater proportion of males at the size range of $120-160 \mathrm{~mm}$ SL (Table 1). Both factors could explain why there were more males than females at the ages of 7-9 years. It also is possible that the fishery has inflated the proportion of males at smaller sizes. Males have a lower maximum size and mature at smaller sizes than females. We define large whelk as those individuals $>160$ $\mathrm{mm}$ SL because this size is slightly above the female $\mathrm{SM}_{50}$ and is equivalent to the 97.5 percentile of male SL (on the basis of a sample of 9460 whelk; B. Stevens, unpubl. data). Because the fishery is directed at catch of large whelk, which are mostly females, fishermen do not actively target males and males may accumulate at smaller sizes.

However, it is possible that knobbed whelk may exhibit protandric behavior in extreme conditions; Castagna and Kraeuter (1994) held only male knobbed whelk in the laboratory. Whelks generally grow slowly and move slowly, and, at low population levels, interaction between sexes may be minimal. Protandry in knobbed whelk may be opportunistic, and not every individual may be capable of it. In addition, unknown pollutants potentially could cause the sex change seen in knobbed whelk by Castagna and Kraeuter (1994). Whether or not protandry occurs in channeled whelk, the fishery will remain in peril if mature females are not protected.

There is a lack of evidence to support the hypothesis that protandry may occur in channeled whelk. Further, no channeled whelk with evidence of imposex were found in our study. In gastropods, tributyltin (TBT) causes higher testosterone, which in turn can cause the penis in male bruised nassa (Nassarius vibex) to develop earlier and males to mature earlier (Demaintenon, 2001). Female bruised nassa with imposex developed a penis, and that development caused sterility in some cases because the penis blocked the oviduct (Demaintenon, 2001). Females with imposex can be confused with sequential hermaphrodites in sex transition because individuals may have both male and female sex organs. Castagna and Kraeuter (1994) indicated that knobbed whelk could be sequential hermaphrodites because some male knobbed whelk switched sex to female in the laboratory, and some of the newly formed female knobbed whelk laid viable egg strings. However, it is possible that their knobbed whelk were originally females with imposex, or that sex change was the result of social and physiological effects of confinement in a laboratory setting.

Gonad histology of the "male" channeled whelk that was abnormally large (more than $20 \mathrm{~mm}$ longer than the second-largest male) revealed that its gonad was nonfunctional. The gonad was empty of any male or female gonadal precursors and contained only connective tissue. The sizes of the penis and gonads were much smaller in this abnormally large male than in fully mature male channeled whelk in the size range of 150 $160 \mathrm{~mm}$ SL. Because the testis and penis were very small, this whelk may never have been reproductively viable or was too old to reproduce. However, it is still possible that this large male was exhibiting protandric or even imposex conditions.

The gonads of only 3 of 115 female channeled whelk contained different dominant stages in the replicate slides; males did not have different dominant stages $(n=112)$. This finding indicates that gonadal development was mostly synchronous. Mann et al. (2006) reported asynchrony for 2 of 3 male specimens of Rapana venosa but not for female specimens collected in June from the Chesapeake Bay. The gonad developmental stages determined for channeled whelk in this study are point-in-time estimates and do not provide a seasonal evaluation. Gonad samples from our study were collected in July and August, most likely at the beginning of the spawning season for channeled whelk (Betzer and Pilson, 1974). The I and ED stages were differentiated to determine when spermatozoa (males) and nuclei (females) were first produced.

Male maturity was determined mostly by the presence and amount of spermatozoa. We believed that a male was capable of spawning effectively if it contained spermatozoa in at least $50 \%$ of its tubules, and we labeled such whelk in our study as mature. A LD-stage male that contained spermatozoa in $25-50 \%$ of its tubules could potentially spawn, but it may not contribute enough spermatozoa to be considered effective.

There is no paternity information on egg strings of channeled whelk, but this species could follow a similar reproductive strategy to that of knobbed whelk. Walker et al. (2005) reported sex-linked markers in knobbed whelk that can be used to determine the biological parents of embryos. A knobbed whelk egg string contained 7 different fathers, indicating that the female knobbed whelk most likely used a "well-blended sperm pool" for fertilization (Walker et al., 2007). Female knobbed 
whelk may copulate with multiple males to increase fitness or because males do not excrete enough spermatozoa to fertilize an entire female brood. If male channeled whelk copulate with multiple females, then it is possible that males do not use all their spermatozoa on one female; this "sperm conservation" strategy of sperm competition is common among snow crab (Chionoecetes opilio) when the ratio of females to males is high (Rondeau and Sainte-Marie, 2001; Sainte-Marie et al., 2002).

Female maturity was determined mainly by the presence of VOs. We assumed a gonad with VOs that covered more than half the cross section could be capable of reproduction, although fecundity could be lower in a female with such a gonad than in a fully matured female. A LD-stage female contained VOs in less than half the cross section and most likely would not reproduce until 1-2 years later.

Staging of gonad development for male channeled whelk was more consistent than staging for females because there were a greater proportion of males at smaller SLs. Males accumulated at smaller size classes (110-160 mm SL) because of a slower growth rate and a lower maximum size than the growth and size of females. In contrast, females grew rapidly past the shorter SL of males. Male and female channeled whelk classified as stage LD may not spawn until the following year because channeled whelk typically grow slowly and would have to overcome a large deficit in gonadal development in just a few months to be considered mature. This large deficit in gonadal development is especially evident in females that probably invest more energy into reproduction than males. Females in stage $\mathrm{R}$ were not present at sizes $>190 \mathrm{~mm}$ SL (Fig. 5A).

It is not known if larger females ( $>190 \mathrm{~mm}$ SL) spawn every year, every other year, or multiple times per year. Bruce et al. ${ }^{3}$ suggested that female knobbed whelk with gravid ovaries (comparable to a mature female) may stay in this state year-round and consequently, not spawn annually. In our study, smaller female channeled whelk ( $<190 \mathrm{~mm}$ SL) classified in the $R$ stage could have spawned earlier in the year or in the previous year. Large females also may not completely deplete their ovaries when they spawn, as we observed in some smaller females, and, therefore, may have a shortened generation time. Large females also may have been ready to spawn after we sampled them in July and August. This circumstance may have been the reason why few females were classified as stage R. Reduced fecundity at older age or larger size, although unlikely, also could be a reason that no females in stage $R$ were found at sizes $>190 \mathrm{~mm}$ SL.

\section{Conclusions}

On the basis of the morphological and histological evidence collected in our study, we suggest that most channeled whelk do not change sex, although chan- neled whelk under some conditions may exhibit protandric-like symptoms (as did the unusually large male in our study). We did not find any channeled whelk with both a penis and nidamental gland or both ovary and testes. All female whelk contained a nidamental gland and ovary. All male whelk contained a penis and testes, except for the large male that contained a penis and an inactive gonad. Penis length increased with SL in males, indicating that channeled whelk are not protandric. Females reached a larger maximum size and age and had a quicker growth rate than males. With the current minimum size limit, this fishery captures small females before they reach $\mathrm{SM}_{50}$ and males just after $\mathrm{SM}_{50}$. To prevent the occurrence of overfishing, fishery managers need to consider the sex-specific growth rates, $\mathrm{SM}_{50}$, and fecundity of channeled whelk. More information on population estimates are needed to understand if the channeled whelk population in Massachusetts is being overfished. The results from this study provide information necessary for managers to work with lawmakers to enact appropriate legislation on size limits to secure the longevity of the Massachusetts whelk fishery and to allow potential mature females to spawn.

\section{Acknowledgments}

This project was supported by the Saltonstall-Kennedy (S-K) Grant Program (grant no. NA10NMF4270007) and the Living Marine Resources Cooperative Science Center for salary of B. Stevens. We thank R. Bemis, S. Lawrentz, and K. Amagada for their help capturing and measuring channeled whelk and C. Conroy and S. Lawrentz for their contributions in aging opercula. S. Lawrentz also assisted greatly with histology. Special thanks go to the University of Massachusetts Dartmouth for allowing us to use their Sea Water Laboratory and to fisherman J. Drake for his assistance and experience in capturing channeled whelk.

\section{Literature cited}

Avise, J. C., A. J. Power, and D. Walker.

2004. Genetic sex determination, gender identification and pseudohermaphroditism in the knobbed whelk, Busycon carica (Mollusca: Melongenidae). Proc. R. Soc. Lond., Ser. B: Biol. Sci. 271:641-646.

Berg, C. J., Jr., and D. A. Olsen.

1989. Conservation and management of queen conch (Strombus gigas) fisheries in the Caribbean. In Marine invertebrate fisheries (J. F. Caddy, ed.), p. 421-442. John Wiley and Sons, New York.

Betzer, S. B., and M. E. Q. Pilson.

1974. The seasonal cycle of copper concentration in Busycon canaliculatum L. Biol. Bull. Mar. Biol. Lab. Woods Hole 146:165-175.

Bourdeau, P. E.

2010. An inducible morphological defence is a passive 
by-product of behavior in a marine snail. Proc. R. Soc. Lond., Ser. B: Biol. Sci. 277:455-462.

Bruce, D. G.

2006. The whelk dredge fishery of Delaware. J. Shellfish Res. 25:1-13.

Castagna, M., and J. N. Kraeuter.

1994. Age, growth rate, sexual dimorphism and fecundity of knobbed whelk Busycon carica (Gmelin, 1791) in a western mid-Atlantic lagoon system, Virginia. J. Shellfish Res. 13:581-585.

Davis, J. P., and R. T. Sisson.

1988. Aspects of the biology relating to the fisheries management of New England populations of the whelks, Busycotypus canaliculatus and Busycon carica. J. Shellfish Res. 9:453-460.

Demaintenon, M. J.

2001. Ontogeny of the pseudohermaphroditic reproductive system in Nassarius vibex (Gastropoda: Buccinidae: Nassariinae). J. Molluscan Stud. 67:51-57.

Edwards, A. L., and M. G. Harasewych.

1988. Biology of recent species of the subfamily Busyconinae. J. Shellfish Res. 7:467-472.

Eversole, A. G., W. D. Anderson, and J. J. Isely.

2008. Age and growth of the knobbed whelk Busycon carica (Gmelin 1791) in South Carolina subtidal waters. J. Shellfish Res. 27:423-426.

Giménez, J., and P. E. Penchaszadeh.

2003. Size at first sexual maturity in Zidona dufresnei (Caenogastropoda: Volutidae) of the south-western Atlantic Ocean (Mar del Plata, Argentina). J. Mar. Biol. Assoc. U.K. 83:293-296.

Gordon, D. A.

1994. Lingcod fishery and fishery monitoring in southeast Alaska. Alaska Fish. Res. Bull. 1(2):140-152.

Harding, J. M.

2011. Observations on the early life history and growth rates of juvenile channel whelks Busycotypus canaliculatus (Linnaeus, 1758). J. Shellfish Res. 30(3):901-903.

Herbst, S. J., and J. E. Marsden.

2011. Comparison of precision and bias of scale, fin ray, and otolith age estimates for lake whitefish (Coregonus clupeaformis) in Lake Champlain. J. Great Lakes Res. 37:386-389.

Heude-Berthelin, C., L. Hégron-Macé, V. Legrand, A. Jouaux,

B. Adeline, M. Mathieu, and K. Kellner.

2011. Growth and reproduction of the common whelk Buccinum undatum in west Cotentin (Channel), France. Aquat. Living Resour. 24:317-327.

Ilano, A. S., K. Fuginaga, and S. Nakao.

2003. Reproductive cycle and size at sexual maturity of the commercial whelk Buccinum isaotakii in Funka Bay, Hokkaido, Japan. J. Mar. Biol. Assoc. U.K. 83:1287-1294.

Ilano, A. S., A. Ito, K. Fujinaga, and S. Nakao.

2004. Age determination of Buccinum isaotakii (Gastropoda: Buccinidae) from the growth striae on operculum and growth under laboratory conditions. Aquaculture 242:181-195.
Kideys, A. E., R. D. M. Nash, and R. G. Hartnoll.

1993. Reproductive cycle and energetic cost of reproduction of the neogastropod Buccinum undatum in the Irish Sea. J. Mar. Biol. Assoc. U.K. 73:391-403.

Kraeuter, J. N., M. Castagna, and R. Bisker. 1989. Growth rate estimates for Busycon carica (Gmelin, 1791) in Virginia. J. Shellfish Res. 8:219-225.

Magalhaes, $\mathrm{H}$.

1948. An ecological study of the genus Busycon at Beaufort, North Carolina. Ecol. Monogr. 18(3):377-409.

Mann, R., J. M. Harding, and E. Westcott.

2006. Occurrence of imposex and seasonal patterns of gametogenesis in the invading veined rapa whelk Rapana venosa from Chesapeake Bay, USA. Mar. Ecol. Prog. Ser. 310:129-138.

Pollock, L. W.

1998. A practical guide to the marine animals of northeastern North America, 367 p. Rutgers Univ. Press, New Brunswick, NJ.

Ricker, W.

1975. Computation and interpretation of biological statistics of fish populations, 382 p. Bull. Fish. Res. Board Can. No. 191.

$\mathrm{R}$ Development Core Team.

2011. R: a language and environment for statistical computing. R Foundation for Statistical Computing, Vienna, Austria. [Available from http://www.R-project. org.]

Rondeau, A., and B. Sainte-Marie.

2001. Variable mate-guarding time and sperm allocation by male snow crabs (Chionoecetes opilio) in response to sexual competition, and their impact on the mating success of females. Biol. Bull. Mar. Biol. Lab. Woods Hole 201:204-217.

Sainte-Marie, B., J.-M. Sevigny, and M. Carpentier.

2002. Interannual variability of sperm reserves and fecundity of primiparous females of the snow crab (Chionoecetes opilio) in relation to sex ratio. Can. J. Fish. Aquat. Sci. 59:1932-1940.

Stoner, A. W., K. W. Mueller, N. J. Brown-Peterson, M. H. Davis, and C. J. Booker.

2012. Maturation and age in queen conch (Strombus gigas): urgent need for changes in harvest criteria. Fish. Res. 131-133:76-84.

Turner, J. T., D. G. Borkman, J. A. Lincoln, D. A. Gauthier, and C. M. Petitpas.

2009. Plankton studies in Buzzards Bay, Massachusetts, USA. VI. Phytoplankton and water quality, 1987 to 1998. Mar. Ecol. Prog. Ser. 376:103-122.

Walker, D., A. J. Power, and J. C. Avise.

2005. Sex-linked markers facilitate genetic parentage analyses in knobbed whelk broods. J. Hered. 96:108-113.

Walker, D., A. J. Power, M. Sweeney-Reeves, and J. C. Avise.

2007. Multiple paternity and female sperm usage along egg-case strings of the knobbed whelk, Busycon carica (Mollusca; Melongenidae). Mar. Biol. 151: 53-61. 